\title{
Identification of quantitative trait loci for resistance against soybean sudden death syndrome caused by Fusarium tucumaniae
}

\author{
Naoki Yamanaka ${ }^{(1)}$, Francisco Horacio Fuentes ${ }^{(2)}$, Javier Ramon Gilli(2), Satoshi Watanabe ${ }^{(1)}$, Kyuya Harada ${ }^{(3)}$, \\ Tomohiro Ban ${ }^{(1)}$, Ricardo Vilela Abdelnoor ${ }^{(4)}$, Alexandre Lima Nepomuceno ${ }^{(4)}$ and Yoshihisa Homma ${ }^{(1)}$ \\ (1) Japan International Research Center for Agricultural Sciences, 1-1 Owashi, Tsukuba, Ibaraki, 305-8686, Japan. \\ E-mail: naokiy@jircas.affrc.go.jp, nabemame@affrc.go.jp, tomohiro@affrc.go.jp, hommay@jircas.affrc.go.jp (2)Instituto Nacional de Tecnología \\ Agropecuaria, Estación Experimental Agropecuaria Marcos Juárez, Casilla de Correo 21, 2580 Marcos Juárez, Córdoba, Argentina. \\ E-mail: ffuentes@correo.inta.gov.ar, jgilli@correo.inta.gov.ar (3)Faculty of Horticulture, Chiba University, 648 Matsudo, Matsudo, Chiba, \\ 271-8510, Japan. E-mail: haradaq@faculty.chiba-u.jp (4)Embrapa Soja, Rod. Carlos João Strass, Caixa Postal 231, CEP 86001-970 Londrina, PR. \\ E-mail: ricardo@cnpso.embrapa.br, nepo@cnpso.embrapa.br
}

\begin{abstract}
The objective of this work was to identify genomic regions that underlie resistance to Fusarium tucumaniae sp. nov., the causing agent of sudden death syndrome (SDS) in soybean in South America, using a population with a genetic background different from that previously reported for Fusarium virguliforme sp. nov. (F. solani f. sp. glycines), also responsible for SDS in soybean. Although major genes and quantitative trait loci (QTL) for SDS resistance have been identified, little is known about the same disease caused by Fusarium tucumaniae sp. nov., in South America. To identify genetic factors related to resistance to F. tucumaniae and DNA markers associated with them, a QTL analysis was performed using recombinant inbred lines. The map locations of the four loci, here identified, differed from those SDS resistance QTL previously described. It was screened a residual heterozygous line (RHL), which was heterozygous around the most effective QTL, RSDS1, and homozygous for the other genomic regions. The genetic effect of RSDS1 was confirmed using near-isogenic lines (NIL) derived from the RHL. The line which was homozygous for the Misuzudaizu genotype showed resistance levels comparable with that of the line homozygous for the Moshidou Gong 503 genotype.
\end{abstract}

Index terms: Glycine max, disease index, residual heterozygous line, SDS.

\section{Identificação de locos controladores de características quantitativas para resistência contra a síndrome da morte súbita da soja causada por Fusarium tucumaniae}

\begin{abstract}
Resumo - O objetivo deste trabalho foi identificar as regiões genômicas responsáveis pela resistência ao Fusarium tucumaniae sp. nov., agente causador da síndrome da morte súbita (SDS) da soja na América do Sul, utilizandose uma população com background genético diferente daqueles relatados, anteriormente, para o Fusarium virguliforme sp. nov. (F. solani f. sp. glycines), também responsável por SDS em soja. Embora genes de efeito maior e locos de características quantitativas (QTL) para resistência a SDS tenham sido identificados, pouco se conhece sobre essa mesma doença causada por Fusarium tucumanie sp. nov., na América do Sul. Com a finalidade de identificar fatores genéticos relacionados com a resistência a F. tucumaniae e marcadores de DNA associados a esses fatores, foram conduzidas análises de QTL em linhagens puras recombinantes. A localização de quatro locos identificados diferem de QTL anteriormente descritos para resistência à SDS. Uma linha heterozigótica residual (RHL) foi analisada e mostrou-se heterozigótica próxima ao QTL mais efetivo, RSDS1, e homozigótica para outras regiões genômicas. O efeito genético de RSDS1 foi confirmado, usando-se linhas quase-isogênicas derivadas da RHL. Observou-se que a linha homozigótica para o genótipo Misuzudaizu mostrou resistência similar à da linha homozigótica para o genótipo Moshidou Gong 503.
\end{abstract}

Termos para indexação: Glycine max, índice de doença, linha heterozigota residual, SDS.

\section{Introduction}

Soybean sudden death syndrome (SDS) due to the closely related soil-borne fungi Fusarium solani f. sp. phaseoli (Roy et al., 1989; Rupe, 1989; O’Donnell \& Gray, 1995; Achenbach et al., 1996) and F. solani f. sp. glycines (Rupe, 1989; Roy, 1997) results in severe field losses of soybean in the U.S. (Wrather et al., 1995, 1997), Argentina, and Brazil (Rupe \& Hartman, 1999).

A major resistance gene to $F$. solani f. sp. glycines, $R f s$, was divided into $R f s 1$, the gene for resistance to root infection, and $R f t 1$, the gene for resistance to leaf symptoms (Meksem et al., 1999). From the analysis of a population derived from the varieties 'Essex' and 
'Forrest', and an evaluation of leaf symptoms, it is known that quantitative resistance to SDS is derived from a 'Forrest' allele in a region of linkage group $\mathrm{g}$ and an 'Essex' allele in a region of linkage group c2 (Chang et al., 1996).

Using recombinant inbred lines (RIL) from 'Essex' and 'Forrest', Iqbal et al. (2001) identified four quantitative trait loci (QTL) in linkage group g and one QTL each in linkage groups c2 and i. Three additional QTL for resistance to SDS (one in each linkage groups $\mathrm{g}$, $\mathrm{n}$, and c2) were identified by using RIL derived from 'Pyramid' × 'Douglas' (Njiti et al., 2002). These loci convey resistance against SDS; however, in South America, SDS is caused by Fusarium tucumaniae sp. nov., which is phylogenetically and morphologically different from Fusarium virguliforme sp. nov. (synonymous with $F$. solani f. sp. glycines), the causative agent of SDS in North America (Aoki et al., 2003).

The fungi causing SDS and the resistance genes in soybeans have been well studied. However, additional genetic factors may contribute to SDS resistance, because: another species causes SDS in South America; and the previously identified loci were detected by using relatively limited genetic resources.

Although resistance against the disease is difficult to evaluate under reproductive conditions, one strategy that enables to evaluate resistance is to use near-isogenic lines (NIL), for the genomic regions that contribute to resistance. Analysis of complex quantitative traits, by using NIL derived from RIL, can facilitate the identification and fine-mapping of QTL (Haley et al., 1994; Yamanaka et al., 2005). Njiti et al. (1998) confirmed the SDS resistance-related genomic regions in linkage groups c2 and g, by using NIL derived from a RIL of 'Essex' and 'Forrest'.

The objective of this work was to identify the genomic regions that underlie resistance to Fusarium tucumaniae using a population with a genetic background different from previously reported materials.

\section{Material and Methods}

A population of RIL (Watanabe et al., 2004) for evaluating resistance to F. tucumaniae and for QTL analysis was used. A total of 156 RIL was developed by single-seed decent from the $F_{2}$ population. The parentals, Misuzudaizu and Moshidou Gong 503, are relatively susceptible and resistant to $F$. tucumaniae, respectively. In light of the genotypes of DNA markers, a single line (RH1-73) from the 156 RIL $\left(\mathrm{F}_{8}\right)$ was identified as being heterozygous around the QTL that contributed mostly to resistance in this population, RSDS1.

The detailed strategy for screening of the RHL is described in Yamanaka et al. (2005). In order to confirm the homozygosis of RH1-73 (except for the region of $R S D S 1$ ), the genotype data of the DNA markers used for previous map construction were utilized (Yamanaka et al., 2001; Watanabe et al., 2004). A segregating population of 42 individuals $\left(F_{10}\right)$ was obtained by selfing of a single $\mathrm{F}_{9}$ plant, which was heterozygous for the simple sequence repeat (SSR) marker Satt599, the nearest marker to RSDS1. This $\mathrm{F}_{10}$ population was also used for the resistance test.

The fungus F. tucumaniae sp. nov. MJ161 (GenBank accession no. 238407) was used for inoculation. Biological details of this fungus are given in Aoki et al. (2003).

Inocula from a single colony cultured for several days on PDA medium (DIFCO) were transferred to sorghumseed medium and cultured for 20 days at $20^{\circ} \mathrm{C}$, under constant darkness. Fungi cultured in sorghum medium were crushed into powder and, then, prepared for inoculation by mixing with fine-grained vermiculite at $2.5 \%(\mathrm{v} / \mathrm{v})$ (Figure 1).

RIL were inoculated with the fungus by using plastic pot (Paul Forestal SRL, Figure 1) cultivation in a greenhouse, at Marcos Juarez Agricultural Experiment Station, the National Institute for Agricultural Technology in Argentina, in 2002. The selected RIL and the $42 \mathrm{~F}_{10}$ plants were inoculated by means of pot cultivation, in a greenhouse at Jircas in Japan in 2003. In Argentina, 16 plants from each line of RIL population were tested. These tests were performed under the conditions depicted in Figure 1, and the plants were cultivated without nutrition. Symptoms present on the leaves in the plants, and resistance against F. tucumaniae were

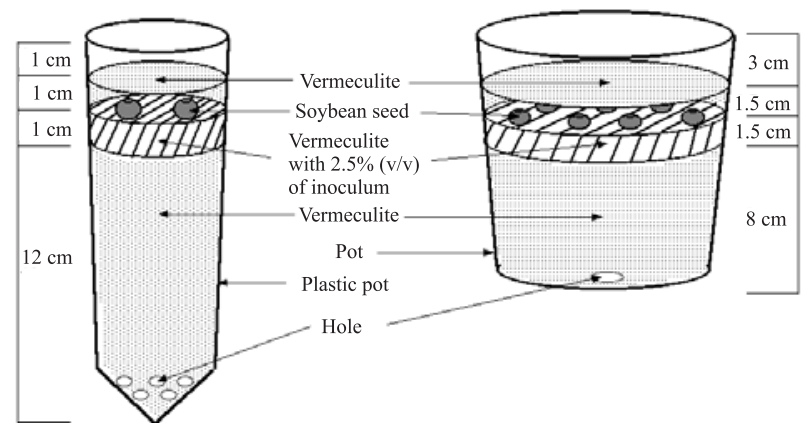

Figure 1. Scheme of inoculation process for evaluation of resistance to soybean sudden death syndrome. Left and right diagrams represent the $15 \mathrm{~cm}$-plastic pot and normal pot, respectively. 
evaluated 40 days after sowing, in the case of plastic pot cultivation, and 14 days after sowing in the case of pot cultivation. The term of cultivation was determined according to the symptoms on parental varieties.

The prevalence of SDS leaf symptoms on each plant was scored according to the following criteria: class 0 , no symptoms; class $1,<25 \%$ of leaves with symptoms; class 2, 25-50\% of leaves affected; class 3, 50-75\%; class 4, >75\%; class 5, plant dead. Disease index (DX; range, 0 to 100) was then calculated with the formula: $\mathrm{DX}=1 / 5 \mathrm{n} \Sigma(0 \mathrm{a}+1 \mathrm{~b}+2 \mathrm{c}+3 \mathrm{~d}+4 \mathrm{e}+5 \mathrm{f})$; in which $\mathrm{n}$ is the number of plants tested, and a, b, c, d, e, and $\mathrm{f}$ are the number of plants in disease classes $0,1,2$, 3 , 4, and 5, respectively $(n=a+b+c+d+e+f)$. Finally, resistance against $F$. tucumaniae was evaluated in light of the DX values from the RIL and from he genotypes derived from the RHL, RH1-73. The DX values obtained from two independent tests using RIL have their correlation confirmed by Pearson's correlation.

The molecular linkage map previously generated for these RIL (Watanabe et al., 2004) was used, and the composite interval mapping (CIM) (Zeng, 1993) was performed using QTL Cartographer version 2.0 (Basten et al., 2001), in order to map and estimate the genetic effects of the QTL associated to plant response against $F$. tucumaniae. A minimum likelihood ratio (LR) value of 4.6, which is equal to the logarithm of the odds favoring linkage (LOD) value of 2.0, was chosen to confirm the presence of a QTL in a genomic region. The SSR marker Satt599 (Cregan et al., 1999) was used for screening an $\mathrm{F}_{9}$ plant suspected as being heterozygous for RSDS1 and for genotyping the $42 \mathrm{~F}_{10}$ individuals. Segregation ratio of Satt599 in this population was checked whether it could fit theoretical ratio, $1: 2: 1$ by $\chi^{2}$ test. The PCR assay conditions were described by Hossain et al. (2000). To analyze the genomic composition of line RH1-73, the genotype of this line was checked in each marker region by using the known genotypes of 526 markers in a $F_{2}$ map, and of
360 markers in a RIL map (Yamanaka et al., 2000, 2001; Watanabe et al., 2004).

\section{Results and Discussion}

The frequency distribution of $\mathrm{DX}$ in the RIL population is showed in Figure 2. Compared with the parentals Misuzudaizu (45.00) and Moshidou Gong 503 (25.00), the DXs of the RIL ranged from 0 to 57.50 (on average, 31.56). In addition, the RIL phenotypes showed continuous distribution as well as transgressive segregation. These findings corroborate both the quantitative inheritance for resistance against F. tucumaniae in this population and the contribution of each parent with particular resistance alleles. To confirm the phenotypes of the RIL, nine representative RIL (Table 1) were chosen and tested. Although the values of DX did not match completely between the two

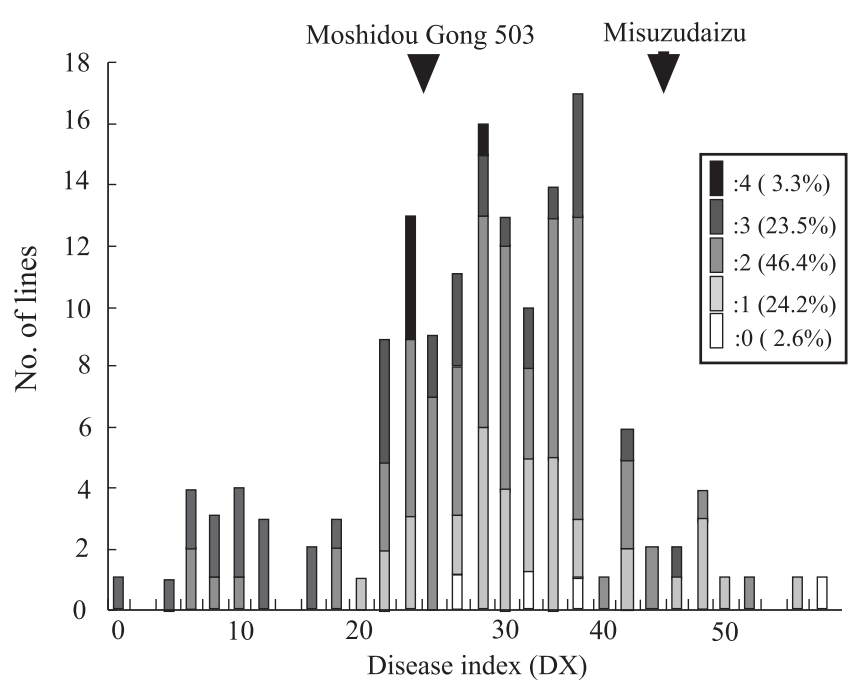

Figure 2. Frequency distribution of disease index (DX) of recombinant inbred lines. Gray scale indicates the putative number of resistance genes among the four quantitative trait loci. Arrowheads indicate the phenotype of parentals.

Table 1. Results of the tests in Argentina (2002) and re-evaluation in Japan (2003), by using representative RIL using Fusarium tucumaniae sp. nov. MJ161.

\begin{tabular}{|c|c|c|c|c|}
\hline Line & DX from QTL analysis (2002) & Putative genotypes $^{(1)}$ of $R S D S I \sim 4$ & No. of plants tested ${ }^{(2)}$ & DX from re-evaluation (2003) \\
\hline RIL 6-20 & 57.5 & $\mathrm{~S}, \mathrm{~S}, \mathrm{~S}, \mathrm{~S}$ & 10 & 54.0 \\
\hline RIL 6-7 & 56.7 & $\mathrm{R}, \mathrm{S}, \mathrm{S}, \mathrm{S}$ & 15 & 53.3 \\
\hline RIL $1-152$ & 52.0 & $\mathrm{~S}, \mathrm{R}, \mathrm{S}, \mathrm{S}$ & 14 & 35.7 \\
\hline RIL 1-4 & 44.9 & $\mathrm{~S}, \mathrm{~S}, \mathrm{R}, \mathrm{R}$ & 14 & 32.9 \\
\hline RIL 1-99 & 21.3 & $\mathrm{~S}, \mathrm{~S}, \mathrm{R}, \mathrm{S}$ & 16 & 41.2 \\
\hline RIL $1-19$ & 20.0 & $\mathrm{R}, \mathrm{S}, \mathrm{S}, \mathrm{R}$ & 13 & 27.7 \\
\hline RIL 1-145 & 13.9 & $\mathrm{R}, \mathrm{R}, \mathrm{S}, \mathrm{R}$ & 16 & 26.3 \\
\hline RIL 1-171 & 11.7 & $\mathrm{R}, \mathrm{R}, \mathrm{S}, \mathrm{R}$ & 14 & 25.7 \\
\hline RIL $1-66$ & 10.8 & $R, R, S, R$ & 17 & 12.9 \\
\hline
\end{tabular}

(1)S: homozygous for the susceptible genotype; R: homozygous for resistant genotype estimated by flanking markers. ${ }^{(2)}$ The number of plants tested for re-evaluation in Japan (2003) 
independent tests, the degrees of resistance were well correlated $(r=0.81)$.

The composite interval mapping (CIM) of the 156 RIL identified four regions of the genome which were associated with DX (Figure 3, Table 2). In linkage group a1, the two QTL RSDS1 and RSDS3 were identified at SSR markers Satt599 and Satt545, respectively. The allele derived from Misuzudaizu contributed to reduce DX at RSDS1, whereas the Moshidou Gong 503 allele reduced DX at RSDS3. The additive effects of these
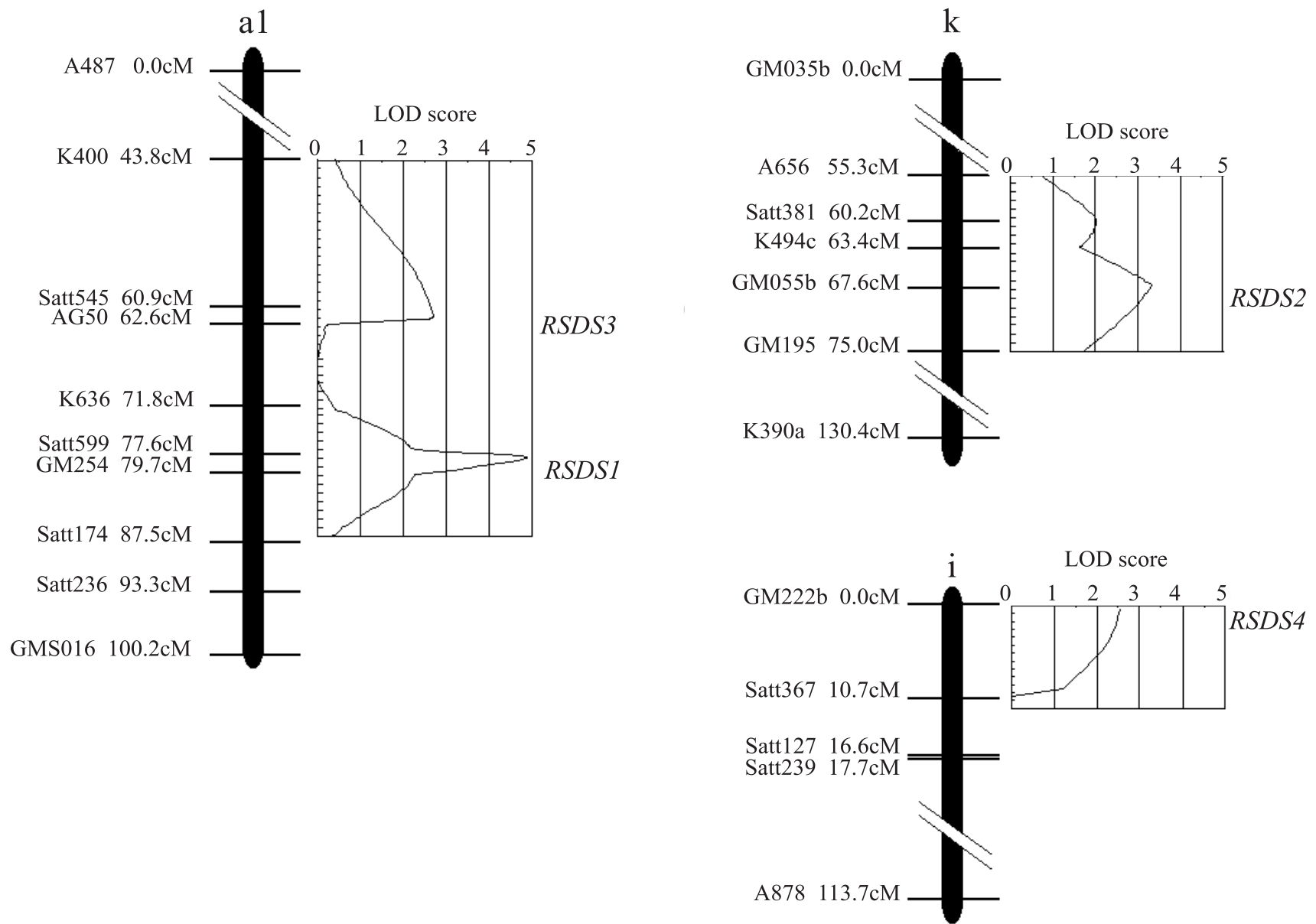

Figure 3. Locations of the quantitative trait loci, identified in the present study, for resistance to soybean sudden death syndrome. Linkage groups are assigned according to the consensus soybean linkage map of Cregan et al. (1999). At the left side of the linkage group are indicated the name of each marker and its genetic distance from the top of the linkage group, as calculated using the Kosambi function. The logarithm of odds (LOD) curve is represented on the right side of the linkage groups.

Table 2. Four QTL associated to resistance against SDS caused by Fusarium tucumaniae sp. nov. MJ161. QTL were ordered and named based on each magnitude of LOD score.

\begin{tabular}{|c|c|c|c|c|c|}
\hline QTL & Flanking marker ${ }^{(1)}$ & Linkage group & LOD score $^{(2)}$ & $\begin{array}{c}\text { Variance explained } \\
(\%)^{(3)}\end{array}$ & $\begin{array}{c}\text { Additive effect }{ }^{(4)} \\
\text { (DX) }\end{array}$ \\
\hline RSDS1 & Satt599 & al & 4.78 & 18.42 & -4.64 \\
\hline RSDS2 & GM055b & $\mathrm{k}$ & 3.31 & 8.71 & 3.19 \\
\hline RSDS3 & Satt545 & a1 & 2.65 & 9.32 & 3.30 \\
\hline RSDS4 & GM222b & $\mathrm{i}$ & 2.52 & 6.61 & 2.78 \\
\hline
\end{tabular}

(1)The markers start with Satt and GM are SSR and RFLP markers, respectively. ${ }^{(2)}$ LOD scores represented here are inverted from LR values obtained by QTL Cartographer. ${ }^{(3)}$ Variance explained of each QTL is that of total phenotypic variance. ${ }^{(4)}$ The effect of one allele of Misuzudaizu genotype in contrast to that of Moshidou Gong 503 genotype. 
two QTL were estimated to reduce DX by 4.64 and 3.30 , respectively (Table 2).

RSDS2 was detected in linkage group $\mathrm{k}$, at restriction fragment length polymorphism (RFLP) marker GM055b, as a QTL whose Moshidou Gong 503 allele reduced DX by an estimated additive effect of 3.19. The linkage group i contained RSDS4 at the RFLP marker GM222b. At this locus, the allele derived from Moshidou Gong 503 was associated with reduction of DX, with an estimated additive effect of 2.78 .

Two QTL, RSDS3 and RSDS4, have their LOD value between 2 and 3, that is the suggestive QTL described by Lander \& Kruglyak (1995). In addition, segregation distortion is one factor that hinders precise localization of QTL, and GM222b (the marker nearest to RSDS4) shows a skewed segregation ratio (Watanabe et al., 2004). This distortion makes the allele of Moshidou Gong 503 dominant $\left(\chi^{2}\right.$ value $\left.=4.17\right)$. It is necessary to confirm the existences and genetic effects of RSDS3 and RSDS4, especially RSDS4, by using material showing normal segregation at their nearest markers, because RSDS4 has a small genetic effect amid distorted segregation.

The four QTL identified apparently do not represent all the genetic factors underlying resistance to SDS, in this population, because the estimated variance explained by these four QTL was $<50 \%$ (Table 2 ), and because the genotype combinations based on them did not always represent the phenotypes of the RIL (Figure 2). This discrepancy was probably caused by errors in the phenotypic data and by the difficulty in evaluating resistance against SDS, associated with unstable resistance to F. tucumaniae. Potential solutions to this difficulty include further optimization of the system to reduce stress (Gray \& Achenback, 1996; Njiti et al., 2001), and increased attention to the consistency of components and protocols during the inoculation stage. Nearly $50 \%$ of phenotypic variation of this population was explained by four QTL. This result suggests that screening of lines with strong resistance to SDS by marker-assisted selection could be possible.
Three of the four QTL that were identified were mapped to linkage groups different from those of previously reported QTL for SDS resistance. Iqbal et al. (2001) also identified a QTL on a linkage group i where the nearest marker was Satt354, which is about $18 \mathrm{cM}$ from Satt367 (Cregan et al., 1999), whereas the QTL identified in the present work is about $10.7 \mathrm{cM}$ from Satt367 (Figure 3) in the opposite direction from Satt354. Therefore, these two QTL are different from each other. It is conjectured that the QTL here detected differ from those previously identified for $F$. virguliforme, because different materials for mapping and different fungus isolate were used to inoculate the plants. In addition, the test in greenhouse doesn't make always possible to predict field response of mature plants, because of plant development or inoculum rate (Torto et al., 1996; Njiti et al., 2001). Thus, the difference might be derived from the difference in inoculation condition.

Genotyping of Satt599 in the population derived from RH1-73 showed that of $42 \mathrm{~F}_{10}$ plants used, 9 were homozygous for the Moshidou Gong 503 allele, 23 were heterozygous, and 10 were Misuzudaizu homozygous (Table 3). These frequencies fit the theoretical ratio of 1:2:1 at $1 \%$ level.

In NIL segregating for Satt599, plants carrying the homozygous allele derived from Misuzudaizu had a lower DX than those homozygous for the Moshidou Gong 503 allele. The additive effect of the Misuzudaizu allele estimated from the NIL was -3.56, which is a value close to that obtained from the RIL (-4.64). The heterozygous line, whose DX type was intermediate, did not demonstrate a pronounced dominance effect (value, 0.60). Although RH1-73 was susceptible to F. tucumaniae, despite having two resistance genes (RSDS3 and RSDS4), similar genetic effects on RSDS1 were observed by using NIL and the original mapping population. Two independent tests confirmed the relationship between the NIL and the original mapping population.

Table 3. Evaluation of resistance against SDS, in the population of 42 plants derived from the RHL, for RSDS1. Fusarium tucumaniae sp. nov. MJ161 was used for this evaluation.

\begin{tabular}{lccc}
\hline Satt599 genotype & Putative genotypes ${ }^{(1)}$ of $R S D S 1 \sim 4$ & No. of plants ${ }^{(2)}$ & DX calculated from each genotype \\
\hline Moshidou Gong 503 homozygous & $\mathrm{S}, \mathrm{S}, \mathrm{R}, \mathrm{R}$ & 9 & 71.1 \\
Heterozygous & $\mathrm{H}, \mathrm{S}, \mathrm{R}, \mathrm{R}$ & 23 & 67.0 \\
Misuzudaizu homozygous & $\mathrm{R}, \mathrm{S}, \mathrm{R}, \mathrm{R}$ & 10 & 64.0 \\
\hline
\end{tabular}

${ }^{(1)}$ S: homozygous for susceptible genotype; H, heterozygous; R, homozygous for resistant genotype. ${ }^{(2)}$ The frequencies fitted the theoretical distribution at $1 \%$ level in $\chi^{2}$ test. 
Misuzudaizu is a Japanese cultivar and Moshidou Gong 503 is a Chinese half-wild line, and populations derived from this cross contain many highly polymorphic DNA markers and have been used to discover numerous QTL for diverse characteristics (Yamanaka et al., 2000, 2001; Tajuddin et al., 2003; Watanabe et al., 2004). As expected, progenies of this cross were useful for identifying QTL for resistance against F. tucumaniae. However, the mapping population needs to undergo a further optimized evaluation test, and the effects of RSDS2, RSDS3, and RSDS4 should be confirmed by using RHL for these QTL. The results of these future studies may reveal additional novel QTL, as well as confirm the existence and genetic effects of RSDS2, RSDS3, and RSDS4.

\section{Conclusions}

1. Four QTL associated with soybean response to SDS, caused by Fusarium tucumaniae, are located at linkage groups $\mathrm{a} 1, \mathrm{k}$, and $\mathrm{i}$.

2. They differ from those QTL already described for resistance to SDS caused by F. virguliforme.

3. The presence and genetic effect of the QTL against SDS can be confirmed by using RHL.

\section{Acknowledgements}

To Jircas, for supporting this study.

\section{References}

ACHENBACH, L.A.; PATRICK, J.; GRAY, L. Use of RAPD markers as a diagnostic tool for the identification of Fusarium solani isolates that cause soybean sudden death syndrome. Plant Disease, v.80, p.1228-1232, 1996.

AOKI, T.; O’DONNELL, K.; HOMMA, Y.; LATTANZI, A.R. Sudden-death syndrome of soybean is caused by two morphologically and phylogenetically distinct species within the Fusarium solani species complex-F. virguliforme in North America and F. tucumaniae in South America. Mycologia, v.95, p.660-684, 2003.

BASTEN, C.J.; WEIR, B.S.; ZENG, Z.B. QTL cartographer: version 1.15. Raleigh: North Carolina State University, 2001. 162p.

CHANG, S.J.C.; DOUBLER, T.W.; KILO, V.; SUTTNER, R.J.; KLEIN, J.H.; SCHMIDT, M.E.; GIBSON, P.T.; LIGHTFOOT, D.A. Two additional loci underlying durable field resistance to soybean sudden-death syndrome (SDS). Crop Science, v.36, p.1684-1688, 1996.

CREGAN, P.B.; JARVIK, T.; BUSH, A.L.; SHOEMAKER, R.C.; LARK, K.G.; KAHLER, A.L.; KAYA, N.; VAN TOAI, T.T.; LOHNES, D.G.; CHUNG, J.; SPECHT, J.E. An integrated genetic linkage map of the soybean genome. Crop Science, v.39, p.14641490, 1999.

GRAY, L.E.; ACHENBACH, L.A. Severity of foliar symptoms and root and crown rot of soybean inoculated with various isolates and inoculum rates of Fusarium solani. Plant Disease, v.80, p.11971199, 1996.

HALEY, S.D.; AFANADOR, L.K.; MIKLAS, P.N.; STAVELY, J.R.; KELLY, J.D. Heterogeneous inbred populations are useful as sources of near isogenic lines for RAPD marker localization. Theoretical and Applied Genetics, v.88, p.337-342, 1994.

HOSSAIN, K.G.; KAWAI, H.; HAYASHI, M.; HOSHI, M.; YAMANAKA, N.; HARADA, K. Characterization and identification of $(\mathrm{CT})_{n}$ microsatellites in soybean using sheared genomic libraries. DNA Research, v.7, p.103-110, 2000.

IQBAL, M.J.; MEKSEM, K.; NJITI, V.N.; KASSEN, M.A.; LIGHTFOOT, D.A. Microsatellite markers identify three additional quantitative trait loci for resistance to soybean sudden-death syndrome (SDS) in Essex x Forrest RILs. Theoretical and Applied Genetics, v.102, p.187-192, 2001.

LANDER, E.; KRUGLYAK, L. Genetic dissection of complex traits guidelines for interpreting and reporting linkage results. Nature Genetics, v.11, p.241-247, 1995.

MEKSEM, K.; DOUBLER, T.W.; CHANCHAROENCHAI, K.; NJITI, V.N.; CHANG, S.J.C.; RAO-ARELLI, A.P.; CREGAN, P.E.; GRAY, L.E.; GIBSON, P.T.; LIGHTFOOT, D.A. Clustering among loci underlying soybean resistance to Fusarium solani, SDS and SCN in near-isogenic lines. Theoretical and Applied Genetics, v.99, p.1131-1142, 1999.

NJITI, V.N.; DOUBLER, T.W.; SUTTNER, R.J.; GRAY, L.E.; GIBSON, P.T.; LIGHTFOOT, D.A. Resistance to soybean sudden death syndrome and root colonization by Fusarium solani f. sp. glycine in near-isogenic lines. Crop Science, v.38, p.472-477, 1998.

NJITI, V.N.; JOHNSON, J.E.; TORTO, T.A.; GRAY, L.E.; LIGHTFOOT, D.A. Inoculum rate influences selection for field resistance to soybean sudden death syndrome in the greenhouse. Crop Science, v.41, p.1726-1731, 2001.

NJITI, V.N.; MEKSEM, K.; IQBAL, M.J.; JOHNSON, J.E.; KASSEM, M.A.; ZOBRIST, K.F.; KILO, V.Y.; LIGHTFOOT, D.A. Common loci underlie field resistance to soybean sudden death syndrome in Forrest, Pyramid, Essex, and Douglas. Theoretical and Applied Genetics, v.104, p.294-300, 2002.

O’DONNELL, K.; GRAY, L.E. Phylogenetic relationships of the soybean sudden death syndrome pathogen Fusarium solani f. sp. phaseoli inferred from rDNA sequence data and PCR primers for its identification. Molecular Plant-Microbe Interactions, v.8, p.709716, 1995

ROY, K.W. Fusarium solani on soybean roots: nomenclature of the causal agent of sudden death syndrome and identity and relevance of F. solani form B. Plant Disease, v.81, p.259-266, 1997.

ROY, K.W.; LAWRENCE, G.W.; HODGES, H.H.; McLEAN, K.S.; KILLEBREW, J.F. Sudden death syndrome of soybean: Fusarium solani as incitant and relation of Heterodera glycines to disease severity. Phytopathology, v.79, p.191-197, 1989. 
RUPE, J.C. Frequency and pathogenicity of Fusarium solani recovered from soybeans with sudden death syndrome. Plant Disease, v.73, p.581-584, 1989.

RUPE, J.C.; HARTMAN, G.L. Sudden death syndrome. In: HARTMAN, G.L.; SINCLAIR, J.B.; RUPE, J.C. (Ed.). Compendium of soybean diseases. $4^{\text {th }}$ ed. St. Paul: APS Press, 1999. p.37-39.

TAJUDDIN, T.; WATANABE, S.; YAMANAKA, N.; HARADA, $\mathrm{K}$. Analysis of quantitative trait loci for protein and lipid contents in soybean seeds using recombinant inbred lines. Breeding Science, v.53, p.133-140, 2003.

TORTO, G.A.; NJITI, V.; LIGHTFOOT, D.A. Loci underlying resistance to sudden death syndrome and Fusarium solani in field and greenhouse assays do not correspond. Soybean Genetics Newsletter, v.23, p.163-166, 1996.

WATANABE, S.; TAJUDDIN, T.; YAMANAKA, N.; HARADA, K. Construction of linkage map using recombinant inbred lines (RILs) in soybean and identification of QTLs for agronomically important traits. Breeding Science, v.54, p.399-407, 2004.

WRATHER, J.A.; ANDERSON, T.R.; ARSYAD, D.M.; GAI, J.; PLOPER, L.D.; PORTA-PUGLIA, A.; RAM, H.H.; YORINORI, J.T. Soybean disease loss estimates for the top ten producing countries in 1994. Plant Disease, v.81, p.107-110, 1997.
WRATHER, J.A.; CHAMBERS, A.Y.; FOX, J.A.; MOORE, W.F.; SCIUMBATO, G.L. Soybean disease loss estimates for Southern United States, 1974 to 1994. Plant Disease, v.79, p.1076-1079, 1995.

YAMANAKA, N.; NAGAMURA, Y.; TSUBOKURA, Y.; YAMAMOTO, K.; TAKAHASHI, R.; KOUCHI, H.; YANO, M.; SASAKI, T.; HARADA, K. Quantitative trait locus analysis of flowering time in soybean using a RFLP linkage map. Breeding Science, v.50, p.109-115, 2000.

YAMANAKA, N.; NINOMIYA, S.; HOSHI, M.; TSUBOKURA, Y.; YANO, M.; NAGAMURA, Y.; SASAKI, T.; HARADA, K. An informative linkage map of soybean reveals QTLs for flowering time, leaflet morphology and regions of segregation distortion. DNA Research, v.8, p.61-72, 2001.

YAMANAKA, N.; WATANABE, S.; TODA, K.; HAYASHI, M.; FUCHIGAMI, H.; TAKAHASHI, R.; HARADA, K. Fine mapping of the FT1 locus for soybean flowering time using a residual heterozygous line derived from a recombinant inbred line. Theoretical and Applied Genetics, v.110, p.634-639, 2005.

ZENG, Z.B. Theoretical basis for separation of multiple linked gene effects in mapping quantitative trait loci. Proceedings of the National Academy of Sciences of the United States of America, v.90, p.10972-10976, 1993.

Received on October 24, 2005 and accepted on May 17, 2006 